\title{
Mikrometr śrubowy Gottfrieda Kircha - historia, konstrukcja i upowszechnienie w I. poł. XVIII w.
}

\section{Gottfried Kirch's Screw Micrometer - Its History, Design and Dissemination in the First Half of the $18^{\text {th }}$ Century}

Gottfried Kirch (1639-1710) developed the screw micrometer to observe the occultation of o Tauri by Saturn on January $7 / 17,1679$. The news about the instrument was not published immediately. The device was popularised by his calendar for 1696 . The article presents preliminary findings concerning the dissemination of knowledge about this invention and responds to the claim that it was the most widely used micrometer in the German-speaking lands in the first half of the $18^{\text {th }}$ century.

Keywords: Gottfried Kirch, Christfried Kirch, Johann Leonhard Rost, screw micrometer, astronomy

Słowa kluczowe: Gottfried Kirch, Christfried Kirch, Johann Leonhard Rost, mikrometr śrubowy, astronomia

Spośród wszystkich mikrometrów, które są obecnie znane, żaden nie jest wygodniejszy i lżejszy, jak ten, który wymyślił w 1679 r. ś.p. Gottfried Kirch, Królewski Pruski Astronom z Berlina [...] Ponieważ można go przygotować niewielkim kosztem i pokazuje odległości bez wysiłku i dokładnie, od paru lat z przyjemnością się nim posługuję, a zatem wiem, co mówię; więc pozostałe rodzaje mikrometrów przemilczę i przedstawię tylko ten'1.

Tymi słowami Johann Leonhard Rost (1688-1727), autor pierwszego niemieckiego podręcznika do astronomii, wydanego w 1718 r. w Norymberdze, określił specyfikę i wyjątkowość mikrometru śrubowego konstrukcji Gottfrieda Kircha (1639-1710). Według autora kompendium, posługującego się instrumentem i formułującego swoją opinię na podstawie własnego doświadczenia obserwacyjnego, narzędzie cechowała wygoda w użyciu, lekkość, precyzja i niskie koszty przygotowania. Zalety te, z których na pierwszym planie była stosunkowo niska cena, sprawiły, że w 1. poł. XVIII w. na obszarze 
niemieckojęzycznym przyrządem tym posługiwano się chętnie w obserwacjach astronomicznych.

Historia mikrometru, przyrządu pomiarowego do wyznaczania odległości kątowej dwóch obiektów na niebie, nieprzekraczającej kilkunastu minut kątowych, sięga XVII w. ${ }^{2}$ Wiązała się nierozerwalnie z rozwojem teleskopu, gdyż upowszechnienie i ulepszenie tego instrumentu rodziło potrzebę znalezienia sposobu pomiarów małych odległości kątowych, przekraczających zdolność rozdzielczą oka ludzkiego. Jako pierwszy zastosował mikrometr do pomiarów astronomicznych Anglik William Gascoigne (1612-1644), wykorzystując możliwości, które oferował teleskop Keplera. Konstrukcja wynalazku, którego powstanie datuje się na lata 1638-1639, polegała na umiejscowieniu skrzyżowanych nitek, przesuwających się za pomocą śruby w płaszczyźnie ogniskowej okularu teleskopu³.

Śmierć Gascoigne'a w 1644 r. sprawiła, że o przyrządzie wiedziało tylko grono jego przyjaciół - William Oughtred (1574-1660) i Richard Towneley (1629-1707). Do publicznego dyskursu mikrometr Gascoigne'a trafił dopiero w wyniku sporu o pierwszeństwo tego wynalazku, jaki rozegrał się w latach 1666-1667. Francuz Adrien Auzout (1622-1691) we współpracy z Jeanem-Félixem Picardem (1620-1682), inspirując się pomysłem Christiaana Huygensa (1629-1695), stworzył kolejny model mikrometru. W jego konstrukcji wykorzystane zostały dwie równoległe nitki, jedna stała, druga poruszana za pomocą śruby ${ }^{4}$.

Nie były to jednak jedyne znane koncepcje mikrometru. Druga połowa XVII w. przynosiła kolejne próby udoskonalenia tego przyrządu. Podjęli je: Eustachio Divini (1610-1685), Robert Hooke (1635-1703), Christiaan Huygens, Cornelio Malvasia (1603-1664), Olaus Rømer (1644-1710) i Christopher Wren (1632-1723). Niezależne od siebie inicjatywy stworzenia takiego przyrządu, podejmowane przez wielu badaczy równocześnie, świadczyły o tym, jak duże było wówczas zapotrzebowanie na instrument precyzyjnie mierzący niewielkie odległości kątowe w obserwacjach astronomicznych ${ }^{5}$.

Z tej właśnie potrzeby brał się wynalazek Gottfrieda Kircha. Moment konstrukcji mikrometru śrubowego, śledzony z perspektywy kariery uczonego, przypadał na sam początek jego działalności obserwacyjnej. Astronom urodził się 8/18 grudnia 1639 r. w Gubinie na Dolnych Łużycach. Z niewielu wzmianek zachowanych o jego młodości dowiadujemy się, że z rodzinnego miasta wyjechał w poszukiwaniu zatrudnienia ${ }^{6}$. Zanim związał swoje przyszłe utrzymanie z pisaniem kalendarzy, pracował jako nauczyciel, najpierw w Langgrün koło Greiz, później w Neundorf nieopodal Lobbenstein7. W 1674 r. gościł

2 H. Hurnik, Instrumenty obserwacyjne astrometrii. Od gnomonu do CCD i interferometru optycznego, Poznań 2000, s. 93-104.

3 R.C. Brooks, The Development of Micrometers in the Seventeenth, Eighteenth and Nineteenth Centuries, "Journal for the History of Astronomy" t. 22, 1991, nr 2, s. 129; J. Hamel, Geschichte der Astronomie. Von den Anfängen bis zur Gegenwart, Basel - Boston - Berlin 1998, s. 213-214; R.C. Brooks, Development of Scale-Reading Micrometers in the Seventeenth to the Nineteenth Centuries, „Bulletin of the Scientific Instrument Society" 2008, nr 98, s. 9.

4 J.A. Repsold, Zur Geschichte der astronomischen Messwerkzeuge von Purbach bis Reichenbach 1450-1830, Leipzig 1908, s. 42; J. North, Historia astronomii i kosmologii, tłum. T. i T. Dworak, Katowice 1997, s. 237.

5 A. Turner, Early Scientific Instruments. Europe 1400-1800, London 1987, s. 133; M. Windelspecht, Groundbreaking Scientific Experiments, Inventions and Discoveries of the $17^{\text {th }}$ Century, Westport, Connecticut - London 2002, s. 164.

6 J.G. Reinbeck, Die Stern=Kunst/ Nach ihrem Mißbrauch und rechten Gebrauch [...], Cölln an der Spree [b.r.], s. $21-22$.

7 K.-D. Herbst, Neue Erkenntnisse zur Biographie von Gottfried Kirch, [w:] 300 Jahre Astronomie in Berlin und Potsdam. Eine Sammlung von Aufsätzen aus Anlaß des Gründungsjubiläums der Berliner Sternwarte, red. 
w gdańskim obserwatorium Jana Heweliusza (1611-1687), gdzie pomagał w obserwacjach i obliczeniach. Od 1676 r. mieszkał Kirch z rodziną w Lipsku ${ }^{8}$. W latach siedemdziesiątych XVII w. drukiem zaczęły ukazywać się jego pierwsze pisma astronomiczne: Stern=Lust, Neues und gewisses Wunder am Himmel, Kurtze Betrachtung derer Wunder am gestirnten Himmel, Eilfertiges Send=Brieflein An einen guten Freund/Von dem Neuen Wunder $=$ Stern am Halse des Walfisches ${ }^{9}$.

Wynalezienie mikrometru śrubowego dokonało się w przeddzień pierwszych, niosących Kirchowi sławę, odkryć astronomicznych. 4/14 listopada 1680 r. dostrzegł kometę, która do historii przeszła jako „wielka”. Szczegóły badań obiektu przedstawił w wydanej rok później pracy Neue Himmels=Zeitung. W 1681 r. rozpoznał gwiazdę mgławicową w gwiazdozbiorze Tarczy (gromada otwarta M11). Kolejnym ważnym osiągnięciem było

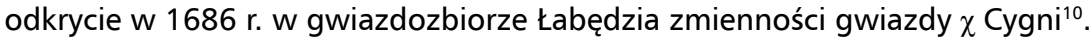

Powstanie mikrometru śrubowego Kircha powszechnie datuje się na 1679 r. Jeżeli jednak zajrzymy do źródeł opisujących historię narodzin wynalazku, dowiemy się, że był to tylko rok, w którym instrument po raz pierwszy został wykorzystany do obserwacji. Jego powstanie brało się z przygotowań astronoma do obserwacji zakrycia przez Saturna gwiazdy 6 wielkości w południowym rogu gwiazdozbioru Byka. Zjawisko przypadało na 7/17 stycznia 1679 r. ${ }^{11}$ Data ta każe zastanowić się nad momentem wynalezienia mikrometru. Dzienniki Kircha nie wskazują na wcześniejsze użycie przyrządu. Możliwe jednak, że sam pomysł na instrument pojawił się znacznie wcześniej.

Koncepcja przyrządu służącego do mierzenia odległości kątowej między dwoma bliskimi obiektami astronomicznymi znana była Kirchowi za sprawą doniesień z "Journal des sçavans” i „Philosophical Transactions”. Wobec braku możliwości znalezienia osoby, która przygotowałaby mikrometr na wzór francuski lub angielski, zrodził się pomysł jego samodzielnego zaprojektowania. Zaletą wymyślonego przez astronoma mechanizmu, jak podkreślał on sam, była jego prostota. Nieskomplikowana konstrukcja była celowym założeniem, chciał on, aby instrument mógł przygotować każdy przeciętny ślusarz ${ }^{12}$.

Wykonaniem mikrometru nie zajął się więc Kirch osobiście, lecz zwrócił się do lokalnego ślusarza, któremu zlecił sporządzenie żelaznego pierścienia, pasującego do jego blaszanego teleskopu o ogniskowej 3 stóp. Pierścień kazał podzielić na dwie identyczne części i wykonać do niego dwie śruby, umieszczone po przeciwnych stronach, które przykręcone do końca się stykały (Ryc. 1) ${ }^{13}$. Po obserwacji z 7/17 stycznia 1679 r. astronom nabył dokładniejszy mikrometr z mosiądzu, a także opracował tabele, na podstawie których można było po zmierzeniu odległości przeliczyć obroty śrub na minuty i sekundy kątowe ${ }^{14}$.

W.R. Dick, K. Fritze, Thun - Frankfurt am Main 2000 (Acta Historica Astronomiae, t. 8), s. 72; idem, Der Astronom Gottfried Kirch (1639-1710) im Vogtland, „Jahrbuch des Museums Reichenfels-Hohenleuben” 2001, z. 46, s. 96.

8 J.G. Reinbeck, op. cit., s. 22; K.-D. Herbst, Neue Erkenntnisse, s. 72-73.

9 Szczegółową biografię Kircha przedstawiam w: J. Rogińska, Gottfried Kirch (1639-1710), życie i działalność pierwszego astronoma Królewskiego Pruskiego Towarzystwa Nauk, „Kwartalnik Historii Nauki i Techniki” t. 66, 2021, nr 3, s. 105-121.

10 K.-D. Herbst, Zum 300. Todestag des Astronomen und Kalendermachers Gottfried Kirch, [w:] Gottfried Kirch (1639-1710) und die Berliner Astronomie im 18. Jahrhundert. Beiträge des Kolloquiums am 6. März 2010 in Berlin-Treptow, red. J. Hamel, Frankfurt am Main 2010 (Acta Historica Astronomiae, t. 41), s. 29.

11 G. Kirch, Christen = Jüden= und Türcken=Kalender/ Auf das Jahr Jesu Christi 1696, Nürnberg [b.r.], k. G 2 .

12 Ibid., k. G, $-\mathrm{G}_{2} \mathrm{v}$.

13 Ibid., k. G $v$.

14 Ibid., k. G ${ }_{2}-G_{3}$ r. Mikrometry śrubowe Gottfrieda Kircha prezentuje: K.-D. Herbst, Die astronomischen Instru- 


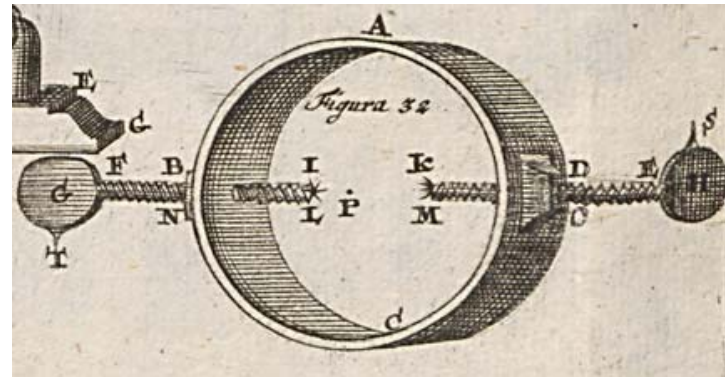

Ryc. 1. Mikrometr śrubowy Gottfrieda Kircha (Źródło: J.L. Rost, Astronomisches Handbuch [...], Nürnberg 1718, Tab. VI, Fig. 32. ETH-Bibliothek Zürich, Rar 2627, doi.org/10.3931/e-rara-16060 / Public Domain Mark).
Zastosowanie skonstruowanego przez Kircha przyrządu polegało na umieszczeniu go w płaszczyźnie ogniskowej teleskopu. Obiekty, których odległość kątową mierzono, umieszczano między dwoma krańcami śrub, położonych na przeciwległych krańcach mikrometru. Następnie obliczano ich rozstaw za pomocą liczby obrotów jednej z nich. W ten sposób uzyskany wynik podawano ze skrótem „p. m." (partes micrometri) ${ }^{15}$.

W publikacjach z przełomu XVIII i XIX w., traktujących o mikrometrze śrubowym Kircha, napotkać można stwierdzenie, że przyrząd ten był w Niemczech w 1. poł. XVIII w. w powszechnym użyciu ${ }^{16}$. W celu zbadania zasadności tego założenia w pierwszej kolejności należy się odnieść do momentu, w którym sam astronom rozpoczął upowszechniać komunikaty o swoim wynalazku. Sięgająca 1679 r. historia narodzin instrumentu nie była bowiem równoznaczna z datą publikacji wiadomości o nim. Przede wszystkim informacja o mikrometrze nie znalazła się w meldunkach z przeprowadzonej 7/17 stycznia obserwacji. Nie pojawiła się na przykład w przesłanej Heweliuszowi (przed 8/18 marca 1679 r.) relacji17. Niezałączona została także do artykułu w efemerydzie na 1683 r., który prezentował uzyskane wtedy wyniki ${ }^{18}$.

Z korespondencji Kircha wynika, że meldunek o wynalazku został zamieszczony we wrocławskim kalendarzu na 1694 r., pisanym przez niego jako kontynuacja serii Johanna Neubartha (1636-1686) ${ }^{19}$. Interesujące jest to, że informacja o mikrometrze (obecnie najstarsza znana) trafiła najpierw do kalendarza niesygnowanego nazwiskiem astronoma. Możemy jedynie przypuszczać, że ograniczona dostępność tego kalendarza przyczyniła się do opublikowania kolejnego meldunku ${ }^{20}$. Tym razem trafił on do Christen $=$ Jüden=

mente von Gottfried Kirch, [w:] Der Meister und die Fernrohre. Das Wechselspiel zwischen Astronomie und Optik in der Geschichte. Festschrift zum 85. Geburtstag von Rolf Riekher, red. J. Hamel, I. Keil, Frankfurt am Main 2007 (Acta Historica Astronomiae, t. 33), s. 208-210, 218. Wartości tych mikrometrów ustalił: J. Hamel, Die Instrumente der Berliner Sternwarte, 1700 bis um 1780, [w:] Gottfried Kirch (1639-1710) und die Berliner Astronomie im 18. Jahrhundert, s. 79-80.

15 G. Kirch, Christen = Jüden = und Türcken= Kalender/ Auf das Jahr Jesu Christi 1696, k. G, v-G ${ }_{3}$.

16 J.S.T. Gehler, Physikalisches Wörterbuch oder Versuch einer Erklärung der vornehmsten Begriffe und Kunstwörter der Naturlehre mit kurzen Nachrichten von der Geschichte der Erfindungen und Beschreibungen der Werkzeuge begleitet in alphabetischer Ordnung, cz. 3, Leipzig 1790, s. 210; J.Ch. Vollbeding, Archiv nützlicher Erfindungen und wichtiger Entdeckungen in Künsten und Wissenschaften zur Erweiterung menschlicher Kenntnisse in alphabetischer Ordnung, Leipzig 1792, s. 425; J.C. Fischer, Geschichte der Physik seit der Wiederherstellung der Künste und Wissenschaften bis auf die neuesten Zeiten, t. 3, Göttingen 1802, s. 175.

17 Die Korrespondenz des Astronomen und Kalendermachers Gottfried Kirch (1639-1710), t. 2, Briefe 1689-1709, red. K.-D. Herbst, Jena 2006, s. 50-52.

18 G. Kirch, Occultatio Stellae fixae in cornu australi Tauri à Saturno observata Lipsiae, Anno 1679, d. 7. (17.) Januarii, [w:] idem, Annus III. Ephemeridum Motuum Coelestium Ad Annum Aerae Christianae M. DC. LXXXIII [...], Lipsiae [b.r.], k. Gr-G,r.

19 Die Korrespondenz, t. 2, s. 185-186; K.-D. Herbst, Die astronomischen Instrumente von Gottfried Kirch, s. 209; idem, Ein Gelehrter zwischen den Welten: Gottfried Kirch und seine aufklärerischen Visionen, [w:] Gottfried Kirch (1639-1710) und die Berliner Astronomie im 18. Jahrhundert, s. 145-146.

20 Die Korrespondenz, t. 2, s. 190 
und Türcken $=$ Kalender na 1696 r., kalendarza serii prowadzonej przez astronoma pod jego własnym nazwiskiem. Znalazł się w nim zarys historii oraz przygotowania przyrządu, jego zastosowania $w$ teleskopie, prowadzenia obserwacji z jego użyciem oraz wykorzystania w badaniach zaćmień Słońca i Księżyca ${ }^{21}$. Dopiero ten załączony do prognostyku dodatek zwrócił powszechniejszą uwagę. Nie był to też ostatni raz, kiedy uczony pisał o mikrometrze w tej serii. Dwa lata później w Christen $=$ Jüden $=$ und Türcken $=$ Kalender na 1698 r. Kirch wyjaśniał metodę znalezienia wartości partes micrometri22. Jeszcze jeden meldunek ukazać się miał według Rosta w tym kalendarzu na 1709 r. $^{23}$

Artykuł o mikrometrze śrubowym do „Miscellanea Berolinensia” przygotował Kirch już jako pierwszy astronom Królewskiego Pruskiego Towarzystwa Nauk. Opis wynalazku trafił do pierwszego tomu czasopisma tej instytucji. W wyniku opóźnienia publikacji periodyku złożony tam przez Kircha materiał dopiero w 1710 r. ukazał się drukiem. Artykuł, zaznaczyć należy, był łacińskojęzycznym opracowaniem meldunku wydrukowanego w Christen $=$ Jüden $=$ und Türcken $=$ Kalender na $1696 \mathrm{r}^{24}$

Zasięg informacji o wynalazku pozwala precyzyjniej wyznaczyć korespondencja Kircha. W przesłanym do Heweliusza 6/16 października 1683 r. liście Kirch objaśniał wartość 1 p. m. (ćwierć gwintu mikrometru); wynosiła ona w jego teleskopie o ogniskowej 1,5 stopy 1'4", a w teleskopie o ogniskowej 4 stóp - 21"25. W liście z 27 czerwca/7 lipca 1694 r. do Adama Adamandego Kochańskiego (1631-1700), który nie mógł dostać kalendarza Neubartha na 1694 r., Kirch zapowiadał, że ów egzemplarz mu dośle albo każe sporządzić z niego odpis tekstu o mikrometrze, aby poczta nie wyszła za drogo ${ }^{26}$. Pod koniec 1695 r. syn Kircha, Gottlieb (ur. 1669), gościł przejazdem w Norymberdze. W trakcie obserwacji u Johanna Philippa von Wurzelbaua (1651-1725) zaprezentować miał mikrometr według koncepcji swojego ojca. Norymberski astronom nabył własny egzemplarz mikrometru27. Johann Jakob Chuno (1661-1715) informował 5/15 marca 1697 r. Kircha o otrzymaniu kalendarza z opisem mikrometru ${ }^{28}$. W wiadomości wysłanej do mieszkającego w Lipsku Urlicha Juniusa (1670-1726) 8/18 maja 1698 r. Kirch pisał: „Mój wynaleziony mikrometr jest taki lekki, w przeciwieństwie do angielskiego, całkiem ciężkiego"29. Instrument komplementował Johann Gebhard Rabener (1632-1701), zaznaczając 7/17 lutego 1700 r., że jest godny pochwały. Rabener, porównując przyrząd do mikrometrów widzianych przez niego u Heweliusza, komentował, że były one trudniejsze w użyciü ${ }^{30}$. Historię wynale-

G. Kirch, Christen $=$ Jüden $=$ und Türcken $=$ Kalender/ Auf das Jahr Jesu Christi 1696, k. G $v_{2}-\mathrm{G}_{4} \mathrm{v}$.

22 Idem, Christen= Jüden= und Türcken=Kalender/ Auf das Jahr Jesu Christi 1698, Nürnberg [b.r.], k. F4v-Gv.

23 J.L. Rost, Astronomisches Handbuch, s. 354

24 G. Kirch, De simplicissima quadam specie Micrometri, „Miscellanea Berolinensia ad incrementum scientiarum, ex scriptis Societati Regiae Scientarum” [„Miscellanea Berolinensia”] t. 1, 1710, s. 202-205. Por. idem, Christen $=$ Jüden $=$ und Türcken $=$ Kalender/ Auf das Jahr Jesu Christi 1696, k. G $\mathrm{v}_{2} \mathrm{G}_{3} \mathrm{v}$.

25 Die Korrespondenz des Astronomen und Kalendermachers Gottfried Kirch (1639-1710), t. 1, Briefe 16651689, red. K.-D. Herbst, Jena 2006, s. 269; J. Hamel, Die Instrumente der Berliner Sternwarte, s. 79.

26 Die Korrespondenz, t. 2, s. 190.

27 Die Korrespondenz des Astronomen und Kalendermachers Gottfried Kirch (1639-1710), t. 3, Übersetzungen, Kommentare, Verzeichnisse, red. K.-D. Herbst, Jena 2006, s. 424; K.-D. Herbst, Wer half dem Astronomen Gottfried Kirch?, [w:] Unsichtbare Hände. Zur Rolle von Laborassistenten, Mechanikern, Zeichnern u. a. Amanuenses in der physikalischen Forschungs- und Entwicklungsarbeit, red. K. Hentschel, Diepholz - Stuttgart - Berlin 2008, s. 60.

28 Die Korrespondenz, t. 2, s. 230.

29 Ibid., s. $269-270$.

30 Ibid., s. 388. 
zienia mikrometru przybliżał Kirch Rømerowi w liście wysłanym 25 października 1703 r. Nadmieniał w nim, że jego „prosty mikrometr” dobrze się sprawdzał w obserwacjach ${ }^{31}$.

Dalsze rozpowszechnienie wynalazku prześledzić można w korespondencji syna, Christfrieda Kircha (1694-1740). Christfried znajdował się w bliskiej relacji z największym miłośnikiem mikrometru śrubowego swego ojca, Rostem. Ten norymberski astronom korzystał z instrumentu we własnych obserwacjach, prowadzonych wspólnie z bratem, Johannem Carlem Rostem (1690-1731). O ich pracy z Micrometro Kirchiano wspomina szereg artykułów opublikowanych w „Breslauische Sammlungen” i „Neue Zeitungen von gelehrten Sachen"32. W liście do Christfrieda Kircha z 28 marca 1719 r. Johann Leonhard Rost prezentował nowy sposób używania mikrometru jego ojca ${ }^{33}$.

Listy Rostów dostarczają porównań mikrometru Kircha z innym znanym w 1. poł. XVIII w. mikrometrem według wzoru Philippe'a de La Hire'a (1640-1718). Taki instrument znalazł się w posiadaniu braci po tym, jak podczas spotkania z podróżującym do Petersburga Josephem-Nicolasem Delisle'em (1688-1768), Johann Carl Rost miał okazję go zobaczyć. W liście z 2 maja 1726 r. Johann Leonhard Rost wypowiadał opinię, że mikrometr (instrument miał być gotowy do użytku za kilka dni) będzie zapewne dobry dla precyzyjnych pomiarów, ale mikrometr ojca Kircha wydaje się wygodniejszy w użyciu, ponieważ kiedy noc jest bardzo ciemna, łatwiej rozpoznać śruby niż delikatne nitki. 20 grudnia 1727 r. Johann Carl Rost donosił o niedokładnościach mikrometru de La Hire'a podczas obserwacji zakrycia gwiazdy przez jasną krawędź Księżyca ${ }^{34}$.

Mikrometrem według koncepcji Gottfrieda Kircha był zainteresowany także, wywodzący się z norymberskiego środowiska, Michael Adelbulner (1702-1779), który w listach z 8 czerwca i 8 lipca 1735 r. do Christfrieda Kircha dopytywał się, jakie byłyby koszty przygotowania go w Berlinie. Następnie 18 marca 1736 r. nadmieniał, że ponieważ praca nad instrumentem nie jest jeszcze zaczęta, sprawi go sobie na miejscu ${ }^{35}$.

Kolejny krąg rozpowszechniania wiedzy o mikrometrze śrubowym Kircha wyznaczało berlińskie obserwatorium, osoby w nim pracujące oraz goście. W 1733 r. w Berlinie gościł Anders Celsius (1701-1744). Zaćmienie Słońca z 13 maja tego roku śledził w obserwatorium Królewskiego Pruskiego Towarzystwa Nauk, wyposażony w 7-stopowy teleskop z zadymionym soczewkami. Christfried Kirch i Augustin Grischow (1683-1749) prowadzili obserwacje

31 lbid., s. 461-462.

32 J.C. i J.L. Rost, Von der Conjunctione Veneris \& Spicae Virginis, „Sammlung von Natur= und Medicin- Wie auch hierzu gehörigen Kunst= und Literatur-Geschichten” t. 9, 1719 [dr. 1721], Sommer=Quartal, s. 214; „Neue Zeitungen von gelehrten Sachen" 1724, nr 103, s. 1075; J.L. Rost, Observationes von der Venere, zu Nürnberg An. 1724. tempore correcto, vom 4. Nov. 1724. biß 2. Jan. 1725, „Sammlung von Natur= und Medicin- Wie auch hierzu gehörigen Kunst= und Literatur-Geschichten" t. 30, 1724 [dr. 1726], Herbst=Quartal, s. 613; J.C. i J.L. Rost, Von der Zusammenkunfft Jovis und eines Sternchens sechster Grösse im Aquario, welches Baierus mit dem Buchstaben $h$ bezeichnet hat, „Sammlung von Natur= und Medicin- Wie auch hierzu gehörigen Kunst $=$ und Literatur-Geschichten" t. 31, 1725 [dr. 1726], Winter=Quartal, s. 297.

33 Korespondencję norymberskich astronomów z Christfriedem Kirchem przechowuje Universitätsbibliothek Basel [UB Basel]. Transkrypcje tych listów, przygotowane przez Hansa Gaaba, są dostępne na portalu Astronomie in Nürnberg; Briefwechsel Johann Leonhard Rost, 28. März 1719 (UB Basel, L la 720, k. 51v). Astronomie in Nürnberg, www.astronomie-nuernberg.de [dostęp 14.02.2021].

34 Briefwechsel Johann Leonhard Rost, 2. Mai 1726 (UB Basel, L la 720, k. 138r); Briefwechsel Johann Carl Rost, 20. Dezember 1727 (UB Basel, L la 720, k. 150v). Astronomie in Nürnberg, www.astronomie-nuernberg.de [dostęp 14.02.2021].

35 Briefwechsel Michael Adelbulner: 8. Juni 1735, 8. Juli 1735, 22. Juli 1735, 18. März 1736 (UB Basel, L la 677, k. 45r, 47v, 48r, 49v). Astronomie in Nürnberg, www.astronomie-nuernberg.de [dostęp 14.02.2021]. 
na najwyższym piętrze obserwatorium w zaciemnionym pokoju, rzutując obraz Słońca przez teleskop o ogniskowej 4-5 stóp na białą szybę ${ }^{36}$. W opublikowanych w 1734 r. w „Miscellanea Berolinensia" wynikach badań Celsiusa występuje informacja o wykorzystaniu w pomiarach mikrometru Kircha ${ }^{37}$.

Po śmierci Christfrieda Kircha niektóre instrumenty jego ojca zasiliły zbiory berlińskiego obserwatorium. W inwentarzu z 1768 r. znalazło się kilka teleskopów z mikrometrami Kircha oraz części do teleskopów z tymi mikrometrami ${ }^{38}$. Dyrektorem klasy matematycznej berlińskiej akademii był w latach 1744-1766 Leonhard Euler (1707-1783), który w artykule do „Histoire de l'Académie Royale des Sciences et des Belles-Lettres de Berlin" na 1748 r. wyraził słowa uznania o mikrometrze Kircha ${ }^{39}$.

Popularyzację mikrometru śrubowego Gottfrieda Kircha w 1. poł. XVIII w. wspomóc mogły druki podejmujące problematykę astronomiczną. Jeszcze w 1710 r. opis przyrządu trafił do trzeciego tomu dzieła Christiana Wolffa (1679-1754) Der Anfangs=Gründe Aller Mathematischen Wiessenschaften ${ }^{40}$. W 1718 r. ukazał się Astronomisches Handbuch Johanna Leonharda Rosta. W publikacji tej Rost zachwycał się użytecznością instrumentu, udzielał szczegółowych rad, jak z niego korzystać, a uznając przyrząd za najlepszy w swojej kategorii, nie podjął się w swoim podręczniku do astronomii przedstawienia żadnego innego ${ }^{41}$. Mikrometr śrubowy Kircha prezentował jeszcze Johann Gabriel Doppelmayr (1677-1750). Astronom załączył informacje o przyrządzie do wydanej w 1721 r. trzeciej edycji (Dritte Eröffnung) pracy $\mathrm{Neu}=$ eröffnete Mathematische Werck=Schüle, podjętego w 1712 r. tłumaczenia dzieła Nicolasa Biona (1652-1733) ${ }^{42}$. W Der Aufrichtige Astronomus z 1727 r. przedstawił Rost propozycję ulepszenia wynalazku Kircha (Ryc. 2). Nie był on jedyną osobą, która podjęła się takiego zadania. $Z$ tej pracy dowiadujemy się, że z taką inicjatywą

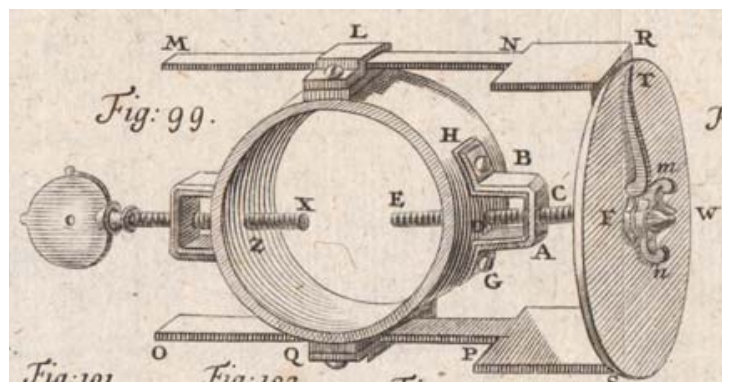

Ryc. 2. Mikrometr śrubowy Gottfrieda Kircha według ulepszeń Johanna Leonharda Rosta (Źródło: J.L. Rost, Der Aufrichtige Astronomus [...], Nürnberg 1727, Tab. XIII, Fig. 99. ETH-Bibliothek Zürich, Rar 4256, doi.org/10.3931/e-rara-2076 / Public Domain Mark).

36 „Neue Zeitungen von gelehrten Sachen” 1733, nr 62, s. 544-546; Ch. Kirch, Eclipsis Solis Anno 1733. Die 13 Maji post meridiem in Observatorio Regio Berolinensi observata, „Miscellanea Berolinensia” t. 4, 1734, s. 230-237.

37 A. Celsius, Phases aliquot Eclipsis Solis Anno 1733 d. 13. Maji st. n. p. m. in Observatorio Regio Berolinensi inter nubes mensuratae, „Miscellanea Berolinensia” t. 4, 1734, s. 239.

38 J. Hamel, Die Instrumente der Berliner Sternwarte, s. 106-107.

39 L. Euler, Sur l'atmosphère de la lune prouvée par la dernière éclipse annulaire du soleil, „Histoire de l'Académie Royale des Sciences et des Belles-Lettres de Berlin" 1748 [dr. 1750], s. 120-121; E. Amburger, Die Mitglieder der Deutschen Akademie der Wissenschaften zu Berlin 1700-1950, Berlin 1950, s. 5.

40 Ch. Wolff, Der Anfangs=Gründe Aller Mathematischen Wiessenschaften Dritter Theil [...], t. 3, Halle 1710, s. 374, 305-306.

41 J.L. Rost, Astronomisches Handbuch, s. 353-358.

42 J.G. Doppelmayr, Dritte Eröffnung der neuen Mathematische Werck=Schule/ Nicolai Bion, in welcher Die Zubereitung und der Gebrauch verschiedener Astronomischen Instrumenten beschrieben, Nürnberg 1721, s. 144-145; H. Gaab, Johann Gabriel Doppelmayr (1677-1750), [w:] Beiträge zur Astronomiegeschichte, red. W.R. Dick, J. Hamel, t. 4, Frankfurt am Main 2001 (Acta Historica Astronomiae, t. 13), s. 62-65. 
wyszedł również Johannes Gaupp (1667-1738) ${ }^{43}$. Podejmowane próby udoskonalenia przyrządu mogą być kolejnym sygnałem jego popularności.

Powołując się na wyżej wymienione pozycje, nie można pominąć informacji, że wynalazek Kircha był prezentowany w nich na tle innych znanych ówcześnie mikrometrów. Początek XVIII w. przynosił bowiem dalsze próby udoskonalenia tego przyrządu pomiarowego. W 1708 r. Constantin Gabriel Hecker (1670-1721) opublikował na łamach „Acta Eruditorum" artykuł o ulepszeniach mikrometru Auzouta przez Heweliusza. Theodor Balthasar w ogłoszonej drukiem w 1710 r. pracy Micrometria przedstawiał kolejne rodzaje mikrometrów. Znany był również wspomniany już mikrometr konstrukcji Philippe'a de La Hire'a ${ }^{44}$. Na obszarze niemieckojęzycznym mógł on zyskać na popularności wraz z pobytem posiadacza tego instrumentu Josepha-Nicolasa Delisle'a w Berlinie i Norymberdze ${ }^{45}$.

Z jakim uznaniem lub krytyką spotkał się mikrometr śrubowy Gottfrieda Kircha w Anglii czy Francji, obecny stan badań nie pozwala jeszcze stwierdzić. Na razie udało się ustalić, że artykuł opisujący mikrometr opublikowany w „Miscellanea Berolinensia” (1710) został przetłumaczony na język angielski i ukazał się w 1743 r. w pierwszym tomie Acta Germanica: or, the Literary Memoirs of Germany ${ }^{46}$. Jednakże Cyclopaedia: or, an Universal Dictionary of Arts and Sciences z 1738 r. świadczy, że do piśmiennictwa anglojęzycznego informacje o mikrometrze trafiły za pośrednictwem „Wolfiusa" ${ }^{47}$. Prawdopodobnie chodzi tu o trzeci tom pracy Wolffa Der Anfangs=Gründe Aller Mathematischen Wiessenschaften z 1710 r. ${ }^{48}$ William Pearson (1767-1847) w drugim tomie An Introduction to Practical Astronomy z 1829 r. wskazywał, że spośród wszystkich form mikrometru śrubowego przyrząd stworzony przez „Kirchiusa” był najprostszy49. Wszystkie przekazy łączy eksponowanie prostoty konstrukcji tego mikrometru.

Na koniec rozstrzygnąć pozostaje, czy Christfried Kirch, syn astronoma, wynalazł własny mikrometr. Po pierwsze, należy zwrócić uwagę na to, że w publikacjach z przełomu XVIII i XIX w., które taką informację podają, wynika ona z mylenia osiągnięć ojca i syna. Dostrzegamy to w drugiej części Anfangsgründe der angewandten Mathematik Abrahama Gotthelfa Kästnera (1719-1800) z 1792 r. Podaje się w niej za autora wynalazku Christfrieda Kircha, ale odwołuje się do stron z artykułu w "Miscellanea Berolinensia”, napisanego przez Gottfrieda Kircha ${ }^{50}$. Podobna pomyłka musiała nastąpić w wydanym w 1810 r. to-

43 J.L. Rost, Der Aufrichtige Astronomus [...], Nürnberg 1727, s. 296-298.

44 G.C.B. Busch, Versuch eines Handbuchs der Erfindungen, cz. 4, Eisenach 1793, s. 143-144; R.C. Brooks, The Development of Micrometers, s. 135-136; idem, Development of Scale-Reading Micrometers, s. 14.

45 S. Dumont, Joseph-Nicolas Delisle's Relations with German Astronomers and Scientists when Travelling to and from Russia (1725-26 and 1747), [w:] The Message of the Angles - Astrometry from 1798 to 1998. Proceedings of the International Spring Meeting of the Astronomische Gesellschaft, Gotha, May 11-15, 1998, Commemorating the First Meeting of Astronomers at the Seeberg Observatory 200 Years Ago, red. P. Brosche, W.R. Dick, O. Schwarz, R. Wielen, Thun - Frankfurt am Main 1998 (Acta Historica Astronomiae, t. 3), s. 43-48.

46 Of a Very Simple Kind of Micrometer. By G. Kirchius. From the Miscellanea Berolinensia. Tom. I. p. 202, [w:] Acta Germanica: or, the Literary Memoirs of Germany [...], t. 1, London 1743, s. 188-191.

47 E. Chambers, Cyclopaedia: or, an Universal Dictionary of Arts and Sciences [...], t. 2, London 1738, k. 6Rr-6Rv.

48 Ch. Wolff, op. cit., s. 374, 305-306.

49 W. Pearson, An Introduction to Practical Astronomy: Containing Descriptions of the Various Instruments That Have Been Usefully Employed in Determining the Places of the Heavenly Bodies, t. 2, London 1829, s. 97; R.C. Brooks, The Development of Micrometers, s. 135. W artykule Brooks mylnie identyfikuje "Kirchiusa” jako Athanasiusa Kirchera (1602-1680).

50 A.G. Kästner, Anfangsgründe der angewandten Mathematik, cz. 2.2, Astronomie, Geographie, Chronologie und Gnomonik, Göttingen 1792, s. 226. 
mie trzecim Fortsetzung und Ergänzungen zu Christian Gottlieb Jöchers allgemeinem Gelehrten-Lexiko, opracowywanym przez Heinricha Wilhelma Rotermunda (1761-1848). W haśle poświęconym Christfriedowi Kirchowi autor przypisuje mu wynalezienie mikrometru śrubowego ${ }^{51}$, powołując się przy tym na pracę Johanna Carla Fischera (1760-1833) Geschichte der Physik seit der Wiederherstellung der Künste und Wissenschaften bis auf die neuesten Zeiten. Na wskazanej stronie tomu trzeciego (1802), znajdziemy jednak poprawnie przypisane autorstwo tego wynalazku Gottfriedowi Kirchowi ${ }^{52}$. Po drugie, ogólna analiza publikacji astronomicznych (bez kalendarzy) Christfrieda Kircha nie wskazuje na razie na to, aby pośród jego osiągnięć znajdował się nowy model mikrometru. Jednakże obecny, bardzo skromny, stan badań na temat jego działalności astronomicznej nie pozwala na całkowite wykluczenie prób udoskonalenia wynalazku ojca.

W historii niemieckiej astronomii mikrometr śrubowy Gottfrieda Kircha zapisał się jako ważny wynalazek. Przygotowany na potrzeby obserwacji 7/17 stycznia 1679 r., został spopularyzowany nie prędzej niż pod koniec lat dziewięćdziesiątych XVII w. W konsekwencji właśnie w 1. poł. XVIII w. mógł wejść do powszechniejszego użytku, przede wszystkim na obszarze niemieckojęzycznym. Zalety przyrządu: lekkość, precyzja, niskie koszty, a w szczególności prosta konstrukcja, umożliwiająca wykonanie przez zwykłego ślusarza, wychodziły naprzeciw potrzeb ówczesnych astronomów. Dzięki temu mógł konkurować z innymi znanymi w tamtych czasach mikrometrami. Chociaż obecny stan badań nie pozwala jeszcze w sposób ostateczny wnioskować o skali upowszechnienia tego instrumentu w 1. poł. XVIII w., wskazać można wstępnie na dwa ośrodki: norymberski i berliński, w których z mikrometru korzystano i z których wiedza o nim promieniowała dalej.

\section{Bibliografia}

\section{Źródła}

Busch G.C.B., Versuch eines Handbuchs der Erfindungen, cz. 4, Eisenach 1793.

Celsius A., Phases aliquot Eclipsis Solis Anno 1733 d. 13. Maji st. n. p. m. in Observatorio Regio Berolinensi inter nubes mensuratae, „Miscellanea Berolinensia” t. 4, 1734, s. 238-239.

Chambers E., Cyclopaedia: or, an Universal Dictionary of Arts and Sciences [...], t. 2, London 1738.

Die Korrespondenz des Astronomen und Kalendermachers Gottfried Kirch (1639-1710), t. 1-3, red. K.-D. Herbst, Jena 2006.

Doppelmayr J.G., Dritte Eröffnung der neuen Mathematische Werck=Schule/ Nicolai Bion, in welcher Die Zubereitung und der Gebrauch verschiedener Astronomischen Instrumenten beschrieben, Nürnberg 1721.

Euler L., Sur l'atmosphère de la lune prouvée par la dernière éclipse annulaire du soleil, „Histoire de l'Académie Royale des Sciences et des Belles-Lettres de Berlin" 1748 [dr. 1750], s. $103-121$.

51 Fortsetzung und Ergänzungen zu Christian Gottlieb Jöchers allgemeinem Gelehrten-Lexiko worin die Schriftsteller aller Stände nach ihren vornehmsten Lebensumständen und Schriften beschrieben werden, red. J.Ch. Adelung, H.W. Rotermund, t. 3, Delmenhorst 1810, s. 374.

52 J.C. Fischer, op. cit., s. 175. 
Fischer J.C., Geschichte der Physik seit der Wiederherstellung der Künste und Wissenschaften bis auf die neuesten Zeiten, t. 3, Göttingen 1802.

Fortsetzung und Ergänzungen zu Christian Gottlieb Jöchers allgemeinem Gelehrten-Lexiko worin die Schriftsteller aller Stände nach ihren vornehmsten Lebensumständen und Schriften beschrieben werden, red. J.Ch. Adelung, H. W. Rotermund, t. 3, Delmenhorst 1810.

Gehler J.S.T., Physikalisches Wörterbuch oder Versuch einer Erklärung der vornehmsten Begriffe und Kunstwörter der Naturlehre mit kurzen Nachrichten von der Geschichte der Erfindungen und Beschreibungen der Werkzeuge begleitet in alphabetischer Ordnung, cz. 3, Leipzig 1790.

Kästner A.G., Anfangsgründe der angewandten Mathematik, cz. 2.2, Astronomie, Geographie, Chronologie und Gnomonik, Göttingen 1792.

Kirch Ch., Eclipsis Solis Anno 1733. Die 13 Maji post meridiem in Observatorio Regio Berolinensi observata, „Miscellanea Berolinensia” t. 4, 1734, s. 230-237.

Kirch G., Christen = Jüden = und Türcken = Kalender/ Auf das Jahr Jesu Christi 1696, Nürnberg [b.r.].

Kirch G., Christen = Jüden = und Türcken = Kalender/ Auf das Jahr Jesu Christi 1698, Nürnberg [b.r.].

Kirch G., De simplicissima quadam specie Micrometri, "Miscellanea Berolinensia” t. 1, 1710 , s. 202-205.

Kirch G., Occultatio Stellae fixae in cornu australi Tauri à Saturno observata Lipsiae, Anno 1679, d. 7. (17.) Januarii, [w:] idem, Annus III. Ephemeridum Motuum Coelestium Ad Annum Aerae Christianae M. DC. LXXXIII [...], Lipsiae [b.r.].

„Neue Zeitungen von gelehrten Sachen” 1724, nr 103; 1733, nr 62.

Of a Very Simple Kind of Micrometer. By G. Kirchius. From the Miscellanea Berolinensia. Tom. I. p. 202, [w:] Acta Germanica: or, the Literary Memoirs of Germany [...], t. 1, London 1743, s. 188-191.

Pearson W., An Introduction to Practical Astronomy: Containing Descriptions of the Various Instruments That Have Been Usefully Employed in Determining the Places of the Heavenly Bodies, t. 2, London 1829.

Reinbeck J.G., Die Stern=Kunst/ Nach ihrem Mißbrauch und rechten Gebrauch [...], Cölln an der Spree [b.r.].

Rost J.C. i J.L., Von der Conjunctione Veneris \& Spicae Virginis, "Sammlung von Natur= und Medicin- Wie auch hierzu gehörigen Kunst= und Literatur-Geschichten" t. 9, 1719 [dr. 1721], Sommer=Quartal, s. 213-219.

Rost J.C. i J.L., Von der Zusammenkunfft Jovis und eines Sternchens sechster Grösse im Aquario, welches Baierus mit dem Buchstaben $h$ bezeichnet hat, "Sammlung von Natur $=$ und Medicin- Wie auch hierzu gehörigen Kunst= und Literatur-Geschichten" t. 31, 1725 [dr. 1726], Winter=Quartal, s. 297-299.

Rost J.L., Astronomisches Handbuch [...], Nürnberg 1718.

Rost J.L., Der Aufrichtige Astronomus [...], Nürnberg 1727.

Rost J.L., Observationes von der Venere, zu Nürnberg An. 1724. tempore correcto, vom 4. Nov. 1724. biß 2. Jan. 1725, „Sammlung von Natur= und Medicin- Wie auch hierzu gehörigen Kunst= und Literatur-Geschichten" t. 30, 1724 [dr. 1726], Herbst=Quartal, s. 613-615. 
Vollbeding J. Ch., Archiv nützlicher Erfindungen und wichtiger Entdeckungen in Künsten und Wissenschaften zur Erweiterung menschlicher Kenntnisse in alphabetischer Ordnung, Leipzig 1792.

Wolff Ch., Der Anfangs=Gründe Aller Mathematischen Wiessenschaften Dritter Theil [...], t. 3, Halle 1710 .

\section{Literatura przedmiotu}

Amburger E., Die Mitglieder der Deutschen Akademie der Wissenschaften zu Berlin 1700 1950, Berlin 1950.

Brooks R.C., Development of Scale-Reading Micrometers in the Seventeenth to the Nineteenth Centuries, „Bulletin of the Scientific Instrument Society” 2008, nr 98, s. 8-23.

Brooks R.C., The Development of Micrometers in the Seventeenth, Eighteenth and Nineteenth Centuries, „Journal for the History of Astronomy” t. 22, 1991, nr 2, s. 127-173, DOI 10.1177/002182869102200202.

Dumont S., Joseph-Nicolas Delisle's Relations with German Astronomers and Scientists when Travelling to and from Russia (1725-26 and 1747), [w:] The Message of the Angles - Astrometry from 1798 to 1998. Proceedings of the International Spring Meeting of the Astronomische Gesellschaft, Gotha, May 11-15, 1998, Commemorating the First Meeting of Astronomers at the Seeberg Observatory 200 Years Ago, red. P. Brosche, W.R. Dick, O. Schwarz, R. Wielen, Thun - Frankfurt am Main 1998 (Acta Historica Astronomiae, t. 3), s. 43-48.

Gaab H., Johann Gabriel Doppelmayr (1677-1750), [w:] Beiträge zur Astronomiegeschichte, red. W.R. Dick, J. Hamel, t. 4, Frankfurt am Main 2001 (Acta Historica Astronomiae, t. 13), s. 46-99.

Gottfried Kirch (1639-1710) und die Berliner Astronomie im 18. Jahrhundert. Beiträge des Kolloquiums am 6. März 2010 in Berlin-Treptow, red. J. Hamel, Frankfurt am Main 2010 (Acta Historica Astronomiae, t. 41).

Hamel J., Geschichte der Astronomie. Von den Anfängen bis zur Gegenwart, Basel Boston - Berlin 1998.

Hamel J., Wissenschaftsförderung und Wissenschaftsalltag in Berlin 1700-1720 - dargestellt anhand des Nachlasses des ersten Berliner Akademieastronomen Gottfried Kirch und seiner Familie, "Sitzungsberichte der Leibniz-Sozietät” t. 55, 2002, z. 4, s. 61-101.

Herbst K.-D., Der Astronom Gottfried Kirch (1639-1710) im Vogtland, „Jahrbuch des Museums Reichenfels-Hohenleuben" 2001, z. 46, s. 95-104.

Herbst K.-D., Die astronomischen Instrumente von Gottfried Kirch, [w:] Der Meister und die Fernrohre. Das Wechselspiel zwischen Astronomie und Optik in der Geschichte. Festschrift zum 85. Geburtstag von Rolf Riekher, red. J. Hamel, I. Keil, Frankfurt am Main 2007 (Acta Historica Astronomiae, t. 33), s. 203-228.

Herbst K.-D., Neue Erkenntnisse zur Biographie von Gottfried Kirch, [w:] 300 Jahre Astronomie in Berlin und Potsdam. Eine Sammlung von Aufsätzen aus Anlaß des Gründungsjubiläums der Berliner Sternwarte, red. W.R. Dick, K. Fritze, Thun - Frankfurt am Main 2000 (Acta Historica Astronomiae, t. 8), s. 71-85.

Herbst K.-D., Wer half dem Astronomen Gottfried Kirch?, [w:] Unsichtbare Hände. Zur Rolle von Laborassistenten, Mechanikern, Zeichnern u. a. Amanuenses in der physi- 
kalischen Forschungs- und Entwicklungsarbeit, red. K. Hentschel, Diepholz - Stuttgart - Berlin 2008, s. 51-68.

Hurnik H., Instrumenty obserwacyjne astrometrii. Od gnomonu do CCD i interferometru optycznego, Poznań 2000.

North J., Historia astronomii i kosmologii, tłum. T. i T. Dworak, Katowice 1997.

Repsold J.A., Zur Geschichte der astronomischen Messwerkzeuge von Purbach bis Reichenbach 1450-1830, Leipzig 1908.

Turner A., Early Scientific Instruments. Europe 1400-1800, London 1987.

Windelspecht M., Groundbreaking Scientific Experiments, Inventions and Discoveries of the $17^{\text {th }}$ Century, Westport, Connecticut - London 2002.

\section{Strony internetowe}

Astronomie in Nürnberg, www.astronomie-nuernberg.de [dostęp 14.02.2021].

dr Justyna Rogińska, doktor nauk humanistycznych w dyscyplinie naukowej historia, adiunkt w Pracowni Historii Nauk Ścisłych Instytutu Historii Nauki im. L. i A. Birkenmajerów PAN. Zainteresowania naukowe: historia wczesnonowożytnej astronomii i meteorologii, kalendariografia niemiecka.

e-mail: jroginska@ihnpan.pl

Data zgłoszenia artykułu: 22 lutego 2021

Data przyjęcia do druku: 14 maja 2021 